\title{
Credit Portfolio Management in Nepalese Commercial Banks
}

\author{
Buddhi Kumar Malla
}

\begin{abstract}
Credit portfolio management is a key function for banks (and other financial institutions, including insurers and institutional investors) with large, multifaceted portfolios of credit, often including illiquid loans (Nario, Pfister, Poppensieker \& Stegemann, 2016). After global financial crisis of 2007-2008, the credit portfolio management function has become most crucial functions of the bank and financial institutions. The Basel III, third installment of Basel accord was developed after crisis to strengthen bank capital requirements by increasing bank liquidity and decreasing bank leverage that encourages banks to measure credit risk of bank's portfolios. The Basel committee also raises an issue concerning the application of the risk weights used in the capital adequacy framework to determine exposure to risk assets for the purpose of determining large credit exposure (Morris, 2001).
\end{abstract}

The portfolio management of the Nepalese banking sector has been improved remarkably during last 10 years due to the strict regulation of Nepal Rastra Bank. This journal will try to describe the present credit portfolio management practice of Nepalese commercial banks by using qualitative and quantitative methods. In this study, concentration of banks for credit portfolio management has been studied by analyzing security wise loan, product wise loan and sector wise concentration of loan where the researcher has found assorted outcomes. This research also aims to provide some suggestions to overcome with problems associated with credit portfolio.

Keywords: Banks, basel, credit portfolio, credit risk management, Nepal, non-performing loan.

\section{Introduction}

Lending is the principal business activity for most commercial banks. The loan portfolio is typically the largest asset and the predominate source of revenue. As such, it is one of the greatest sources of risk to a bank's safety and soundness. Whether due to lax credit standards, poor portfolio risk management, or weakness in the economy, loan portfolio problems have historically been the major cause of bank losses and failures (Comptrollers of the Currency Administrator of National, 1998).

History shows that the major cause of bank's failure is lack of proper credit risk management. Credit risk comes from a bank's dealing with individuals, corporate, banks and financial institutions (BAFI) or a sovereign. It does not necessarily occur in isolation. The same source that compromise credit risk for the bank may also expose it to other risks like operation risk, market risk, liquidity risk etc. A bad portfolio may attract liquidity problem. The soundness and safety of bank is determined by effective credit risk management adopted by bank. Globally 
more than $50 \%$ of total risk in BAFI is derived from poor credit management. Credit risk has been the headline from last few years in Nepal. Many BAFI have been failed due to the credit risk. Nepal Development Bank Limited, Samjhana Finance Limited, United Bikash Bank Limited and Himalayan Finance Limited has been liquidated due to huge non-performing loans. Still there are 11 problematic BAFI as on mid July 2016 due to credit problem.

\section{Literature Review}

Bonti, Kalkbrener, Lotz and Stahl (2005) has suggested the approach for identifying as well as stressing risk concentrations in credit portfolio. The approach to stressing sector concentration uses economic downturn scenarios or market shocks as a starting point and detects concentrations in distinct but highly correlated sectors.

Ivaskeviciute, Macerinskiene and Laura (2008) has suggested that, the loan portfolio should be distributed into sub-portfolios according to activity segments of the bank: large scale projects, corporate and private clients to get more comprehensive results and loan portfolio evaluation.

Afroz (2013) has found that, Bangladesh Krishi Bank, was concentrating its lending to primary agriculture to serve to poor people in rural area. Later on it has diversified its activities to secondary agriculture. After diversification, the financial position of the bank become more transparent and expected for better result soon.

Morris (2001) stated that, In almost all of the countries reviewed, supervisory authorities set limits on large exposures for banks, generally with a limit of about $25 \%$ of a bank's regulatory capital for an individual large exposure to a single borrower or a closely related group of borrowers.

Winton (1999) suggested that, suggests that regulators must be careful in endorsing diversification across multiple sectors or regions as a goal for banks and related intermediaries. Although such diversification may reduce the odds of bank failure and improve bank performance by enhancing monitoring incentives.

Tabak, Fazio and Cajueiro (2010) had studied 96 Brazilian banks and found that, the loan portfolio of Brazilian banks was average, moderate concentrated. He concluded that, loan portfolio concentration seems to improve the performance of Brazilian banks in both return and risk of default. The concentration indices were found to be positively related to returns and negatively related to risks.

\section{Problems and Objectives}

Managing credit risk is the major tasks of risk management in banks today and loan portfolio management is essential for better credit risk management. The credit operation of bank determines its credit portfolio management. This research tries to answer the status of loan portfolio management and techniques adopted by Nepalese commercial banks. 
The present study attempts to achieve the following objectives:

- To know loan portfolio management of Nepalese BAFI.

- To examine the effect of the loan portfolio management in bank's performance.

- To examine the factors influencing loan portfolio management in Nepalese BAFI.

\section{Data and Methods}

The researcher has used both primary and secondary data has been collected and used in this study. The following methods has been used to complete this study. Primary data has been collected via personal interview, telephone interview, direct observation, questionnaires, focus group discussions, experts opinions etc. The researcher has given priority to collect primary data to address the targeted issues and to interpret data better. The data collected from primary sources is always more reliable with low deviations and errors. secondary data has collected from concerned banks. Furthermore, some of the data like research articles, information and data has been obtained from central bank and other necessary information has been downloaded from various websites of government office.

The researcher has selected six commercial banks for this research. The sampling has been chosen from government owned bank, international bank, joint venture bank, upgraded from lower class, younger generation and older generation bank on random sampling method. Eight questions has been developed and pre-tested among 20 persons and interviewed with 200 persons and collected primary data via questionnaire method and analyzed with the help of SPSS software.

Both qualitative and quantitative method of research were applied in this research. Qualitative information were collected via individual or group interview, questionnaire and field survey method. A structural research questionnaire was developed to enquire clear and essential research information. The preliminary finding was discussed with focus groups and experts before conclusion to make research better. The researcher has included the opinion of other stakeholders like regulatory officials and customer before conclusion.

\section{Discussion and Analysis}

Bank's security wise loan portfolio, sector wise loan portfolio and product wise loan portfolio has been analyzed. The followings standard parameter has been taken from NRB Directive (2073) to measure the loan portfolio management of the banks.

- Real estate loan $\leq 25 \%$ of total loan

- Deprived sector loan $\geq 4.5 \%$ of total loan

- Non-performing loan $\leq 5 \%$ of total loan

- Sector wise loan portfolio $\leq 40 \%$ of total loan

The loan portfolio management of the banks can be measured under parameter prescribed by NRB. The real estate loan of banks are below $25 \%$ of total loans. Deprived sector loan of 
Prabhu Bank $4.26 \%$ and Mega bank $4.36 \%$ is found less than $4.5 \%$ but, for the purpose of deprived sector lending it is calculated on the basis of outstanding loan of last 6 months. The outstanding loan of Prabhu Bank as on Mid Jan 2015 was NPR 31,795.65. As per regulatory directives, deprived sector lending of Prabhu will be $6.46 \%$, Similary Mega's outstanding loan as on mid Jan 2015 was 20870.61 , So, deprived sector loan of Mega will be $5.81 \%$ as per central bank's directive. Thus, data illustrates that Nepalese banks are operating under the parameters as that has been issued by NRB, a regulatory body of Nepalese banking sector. Except Prabhu bank, all bank's non-performing loan is below 5\% as per NRB standard, However the average non-performing loan of banks is $2.97 \%$. No banks have exceeded the NRB directive on sector wise loan concentration limit of maximum limit of $40 \%$. The maximum concentration is $32.04 \%$ in wholesaler and retailer by RBB.

The study shows that, Nepalese banks are managing good credit portfolio management. Banks are maintaining different loan products like term loan, overdraft loan, trust receipt/import loan, demand /working capital loan, real estate loan, margin lending, hire purchase loan, deprived sector loan, bills purchase loan and other loan. To control over the concentration risk, banks have distributed loans in various sectors like agriculture, tourism, energy, manufacturing, construction, wholesaler and retailers, transportation, real estate, other services and consumption and other loans.

\section{Credit Portfolio}

Credit portfolio management (CPM) refers to the process of building a series of investments based upon credit relationships and managing the risks involved with these investments. The composition of credit portfolios may be as per the nature and distribution of its loans and may vary upon bank's credit structure. They may classify total credit exposure into purposewise, sector-wise, borrower-type-wise, or even product-wise, security-wise portfolios. It is, however, advantageous to classify large credits into sector-wise portfolios, like priority sector, energy sector, agriculture sector, infrastructure sector, manufacturing sector, trade sector, and real estate sector portfolios, and relatively medium and small-size credits into retail portfolios, like residential housing loan portfolio, auto loan portfolio, personal loan portfolio, education loan portfolio, credit card portfolio, gold loan portfolio etc.

\section{Credit Portfolio Management in Nepal}

The government and concern authorities are majorly focused on development of the country and all the developing countries achievement shows that overall development of country and it is only possible when a country has sound and strong economic growth. After various exploration and studies, the Nepalese authorities have mainly pointed out hierarchy of the sectors which are needed to develop such as Agriculture, Hydropower, Tourism and Various Industrial Productions. With relation to these mentioned sectors NRB too directs its affiliated Banks and Financial Institutions through its Directives to be issued every fiscal year and amends it through circulars as well. 
As per directive no. 2 of NRB directive 2073, BAFI should make provision for possible loss on loans according to their due date. Except pass and watch list category, all classification is considered as non-performing loan. Non-performing loan is the major indicator to measure the assets quality of banks.

\begin{tabular}{llc}
\hline Classification & Criteria of Classification & Provision \\
\hline Pass & No dues and dues unto 3 months loan & $1 \%$ \\
Watch List & $\begin{array}{l}\text { Overdue up to 1 months or expired loan or client's loan } \\
\text { has been categorized into NPL in other banks or restruc- }\end{array}$ & $5 \%$ \\
& tured loan etc. & \\
Substandard & Overdue more than 3 months and up to 6 months & $25 \%$ \\
Doubtful & Overdue more than 6 months and up to 12 months & $50 \%$ \\
Loss & Overdue more than 12 months & $100 \%$ \\
\hline
\end{tabular}

Source: www.nrb.org.np

Similarly, as per NRB directive no.: 3 where the central bank mainly concentrated on the sector wise investment to be disbursed by the Nepalese BAFI in relation to its single obligor limit as well. The macro-economy of Nepal the directives no.: 3 , states that for the economic growth of the country like Nepal, Nepalese BAFI need to diversify its investment portfolio to all potential productive sectors. Further it states that BAFI can only investment either funded or nun-funded up to $25 \%$ of its core capital to single person, group, firm, company or group relating to the borrower. However, banks and financial institutions can investment up to 50\% of its core capital for the project on hydropower, transmission line and cable car construction, as they are being quoted as priority sector by the Nepalese government. For the investment exceeding $25 \%$ of its core capital on hydropower projects power purchase agreement from concern department of ministry should be obtained.

The directives also states that BAFI can limit their investment concentration $40 \%$ maximum on a single sector but it has limited only $10 \%$ to commercial real estate sector and $15 \%$ for residential housing and real estate sector. However banks and financial institution can limit $25 \%$ on real estate and housing in total.

Banks and Financial Institutions needs to report to the central bank on various timely bases regarding their investment port folio such as report no. 9.3 (sector-wise), 9.3ka (productwise) and 9.4 (collateral-wise) as on monthly basis, 2.1 (Classifications of Loans), 2.2 (Loan master list and its provisioning categorization) and 9.12 (Categorization of provision sectorwise) as on quarterly basis, which are being clearly quoted on Directives no.: 9.

NRB Directives no.: 17, quotes that Banks and Financial Institutions need to lend 5\%, 4.5\% and $4 \%$ of its total investment (six month prior total investment is the base) to the deprived sector of the population by 'A-Class', 'B-Class' and 'C-Class' respectively. This Directive is mainly designed for the economic empowerment of underprivileged and rural based populations of the country. Further this directive also states about mandatory investment on priority sector (Agriculture, Energy, Tourism and Urban Public Transport and Small and Cottage Industry) by $20 \%$ for 'A-Class', $15 \%$ for 'B-Class' and $10 \%$ for 'C-Class'. 


\section{Findings}

In this study, the portfolio management, concentration of the banks have been studied by analyzing security wise loan, product wise and sector wise concentration of loans.

\section{Security wise Loan Analysis}

Loan against gold and silver is considered most secured sector for lending. As per sample testing on security wise loan portfolio management of loan against gold and silver, RBB leads the way with $9.53 \%$ followed by Laxmi with $0.65 \%$ and Prabhu Bank with $0.14 \%$ exposures. Rest of banks have no investment in this sector. The overall average lending is $3.01 \%$ on total loans. Similarly, Loan against fixed deposit is also the most secured loan. SBI has highest loan against fixed deposit with $1.96 \%$ and followed by SCB $1.30 \%$, Prabhu $0.33 \%$, RBB $0.29 \%$, Laxmi 0.26 and Mega $0.17 \%$ whose overall average is $0.68 \%$ on total loans.

The data shows that Nepalese banks have lent $87.47 \%$ against collateral i.e. fixed and current assets. The data shows that, Mega has highest exposure in loan against collateral with $96.47 \%$ and followed by Prabhu 88.93\%, Laxmi 88.40, SBI 86.70\%, RBB 85.03\% and SCB 83.93\%. Loan against guarantee is another security for lending. Nepalese banks have lent against government guarantee, personal guarantee, institutional guarantee etc. SCB has highest exposures in loan against guarantee with $5.92 \%$ and followed by SBI $4.51 \%$, Prabhu 3.89\%, Mega 2.87\%, RBB 2.84\% and Laxmi 2.41\%. Data shows banks have $3.59 \%$ overall average on total loans.

Similarly, Loan against other collaterals is another security which includes loan against bills, credit cards etc. RBB has highest loan against these collaterals with $8.86 \%$ and followed by Laxmi $8.28 \%$, SBI $6.82 \%$, Prabhu $6.71 \%$, RBB $2.31 \%$ and Mega $0.49 \%$ with overall average $3.59 \%$ exposures on total loans. As per data, it shows that, it is found out that Nepalese Banks have well managed the security wise loan portfolio. Overall $96.41 \%$ of loan of Nepalese banks are secured by fixed or current assets. Only $3.59 \%$ loan is against guarantee. Nepalese banks have managed loan portfolio in secured collateral which helps in to minimize the risk related to relevant directive.

\section{Sectorwise Loan Analysis}

Banks have average exposures of $3.72 \%$ in agriculture sector where RBB has highest with $6.34 \%$, followed by Prabhu 3.46\%, Mega 2.99\%, SBI 2.63\%, SCB 2.03\% and Laxmi $1.57 \%$. Megha has 5.38\% in tourism sector and followed by Prabhu 5.33\%, RBB 4.66\%, Laxmi 1.38\%, SBI $0.61 \%$ and SCB $0.03 \%$. Banks average loan in tourism sector is $3.17 \%$ on total loans.

Laxmi bank has highest lending in energy sector with $4.53 \%$ and followed by Prabhu $2.49 \%$, Mega $2.27 \%$, SBI $1.72 \%$ and RBB $1.16 \%$. The average lending of banks is $1.96 \%$ on total loans. Selected banks have average $19.05 \%$ lending in manufacturing sector with highest exposure of $30.24 \%$ by SCB and followed by SBI 23.87\%, Mega $23.39 \%$, Laxmi $18.57 \%$, Prabhu $16.72 \%$ and RBB $12.36 \%$. 
SCB has highest exposure in construction sector with $21.28 \%$ and followed by Laxmi with 19.48\%,Prabhu 16.16\%, RBB 11.90\%, SBI 5.48\% and Mega 2.35\%. The average exposure of banks is $12.75 \%$ in average. RBB has highest lending in wholesaler and retailer with $32.09 \%$ and followed by Mega 30.84\%, SBI 29.54, SCB 26.94\%, Laxmi 21.85\% and Prabhu 18.18\%. Selected bank's average lending is $27.10 \%$.

Laxmi bank has highest exposure in transportation with $9.90 \%$ and followed by SBI 3.24\%, Prabhu 3.21\%, RBB 2.34\%, Mega 1.88\% and SCB 0.44\%. Average exposure of banks is 3.47. Similarly, the average exposure of banks in real estate sector is $9.22 \%$ where Prabhu has highest exposure with $14.92 \%$ and followed by Mega $11.48 \%$, Laxmi 9.37\%, RBB 9.32\%, SBI 5.12\% and SCB $4.29 \%$.

Prabhu bank has highest exposures with 9.95\% in other service and followed by Laxmi $3.12 \%$, Mega 2.92\%, RBB 2.80\%, SBI 2.14\% and SCB 0.59\%. Average exposure of selected banks is $3.72 \%$ on total loans. Banks have lent $15.84 \%$ in consumption and other loans. SBI has highest with $25.65 \%$ exposures and followed by RBB $17.02 \%$, Mega 16.50\%, SCB 14\%,Laxmi 10.22\% and Prabhu 9.59\%.

As per the prior and recent data, it is found that Nepalese banks have well managed the sector wise loan portfolio as prescribed by the NRB directives. It also indicates that no Nepalese banks have ever breached the boundary of $40 \%$ limitation on sector-wise loan investment. Similarly, the data also shows the average exposure on business wholesaler and retailer sectors is $27.10 \%$. With all the data and figure on sector-wise lending, which indicates that Nepalese banks have managed figure on sector wise port folio which again helps in to minimize the risk related to relevant directive.

Nepal being a developing country, government has highly focused on development of the country through economic growth. After various exploration and studies, it is found that sector like agriculture, energy and tourism are needed to develop and the potential for the growth of these sectors in the country are optimistically viable. With relation to these mentioned sectors NRB has instructed all its affiliated BAFI through its directives as priority sector lending. However, the result reflects that there is no any significant investment in propriety sector as the data shows only $3.72 \%, 3.17 \%$ and $1.96 \%$ of total loan by major banks of Nepal. It also indicates that Nepalese BAFI have some catch up do in this regard.

As per the directives issued by the central bank \& its current data on real estate and housing sector lending shows that all of the Nepalese banks have followed regulation and are within the frame of $25 \%$ of total loan. The data shows around $9.22 \%$ in an average industry to its total lending.

\section{Product wise Loan Analysis}

As per sample testing of product wise loan analysis of term loan, Prabhu bank leads the way with $20.32 \%$ and followed by Laxmi $16.90 \%$, Mega $15.93 \%$, RBB $13.777 \%$, SCB $6.27 \%$ and SBI $5.91 \%$ with overall average exposure of $13.88 \%$ on term loan. 
Similarly, Mega Bank has highest exposures on overdraft loan with $28.49 \%$ and followed by Prabhu $17.82 \%$, RBB $15.35 \%$, Laxmi $7.67 \%$, SCB $6.37 \%$ and SBI $1.92 \%$. The overall average exposures on this product is $12.69 \%$. Nepalese banks have lent overall average of $4.54 \%$ on total loan on trust receipt/import loan. SCB is leading bank with $11.49 \%$ exposures and followed by Mega 7.62\%, Laxmi 7.48\%, SBI 3.79\%, Prabhu 3.49\% and RBB 0.57\%.

Similarly, Nepalese bank's average exposures on demand and working capital loan is $31.40 \%$ where SBI has highest exposure with $48.94 \%$ and followed by RBB $37.57 \%$, SCB $27.75 \%$, Laxmi $25.70 \%$, Mega $18.75 \%$ and Prabhu $17.61 \%$. The data shows that, SCB has highest exposure in personal housing loan ( up to 10 millions ) with $15.26 \%$ and followed by Prabhu $12.41 \%$, RBB 7.49\%, Laxmi $4.68 \%$, Mega $4.25 \%$ and SBI $3.78 \%$ with overall average of $7.86 \%$ on total loan.

Similarly, the average exposures on real estate of sampled banks is $6.09 \%$ Prabhu has highest exposures with $10.24 \%$ and followed by Mega 8.78, SBI 6.66\%, SCB 5.60\%, RBB 4.13\% and Laxmi $3.13 \%$ with overall average of $6.09 \%$ on total loans. Nepalese banks have lent $1.59 \%$ of total loans on margin lending. Prabhu bank leads the way with $4.58 \%$ and followed by Laxmi $2.37 \%$, RBB $1.43 \%$, Mega $0.32 \%$. SBI and SCB has no exposure in this product.

Similarly, SCB bank in no.1 position in hire purchase loan with $8.85 \%$ and followed by Mega $7.59 \%$, Laxmi $7.56 \%$, Prabhu $5.56 \%$, RBB $3.28 \%$, and SBI $0.86 \%$ with overall average of $4.93 \%$ on total loan. The average exposure of Nepalese banks in deprived sector is $4.85 \%$ where RBB has highest exposure with $5.69 \%$ and followed by SCB $4.73 \%$, Laxmi $4.62 \%$, SBI 4.51\%, Mega 4.36\% and Prabhu 4.26\%.

Similarly, Laxmi has leads in Bills purchase loan with 3.72\% and followed by SBI 1.27\%, SCB $0.86 \%$, RBB $0.07 \%$, Prabhu $0.03 \%$ and Mega has no exposure. The overall average exposure of banks in this product is $0.87 \%$. SBI bank has highest exposure with $22.36 \%$ in other loans and followed by Laxmi $16.16 \%$, SCB $12.84 \%$, RBB 10.66\%, Mega $3.91 \%$ and Prabhu $3.69 \%$. The overall average exposure of banks in this product is $11.81 \%$.

As per data, Nepalese banks have found out that, well managed product wise loan portfolio to manage credit risk. The portfolio risk is found low due to low concentration in single product. However, the average exposure in demand/working capital loan is $31.40 \%$. This product includes various types of business. So that, the overall risk on this product is low. The banks should increase lending on deprived sector to develop nation's economy.

\section{Non-performing Loan}

The data shows that, SBI bank has low non-performing loan with $0.14 \%$ and followed by SCB $0.32 \%$, Mega $0.79 \%$, Laxmi $0.80 \%$, RBB 3.95\% and Prabhu 8.83\%. Except Prabhu bank, all other banks have below 5\% non-performing loan as per standard of NRB directive 2073 , issued to BAFI. However, the average non-performing loan of banks is $2.97 \%$. 


\section{Conclusion}

This study found that, selected commercial banks have managed their loan portfolio as per the standard parameter of NRB directives 2073. All banks have maintained limit of Real estate loan $\leq 25 \%$ of total loan, Deprived sector loan $\geq 4.5 \%$ of total loan, Non-performing loan $\leq 5 \%$ of total loan, Sector wise loan portfolio $\leq 40 \%$ of total loan \& managed credit risk. Banks Non-performing loan shows that, banks are maintaining good credit risk management practice. However, $96.41 \%$ of bank's lending is on collateral basis which indicates that, banks are conservative in lending. Nepalese banks should increase their lending on priority sector and other various type of project based lending to contribute in development of country.

\section{BIBLIOGRAPHY}

Afroz, N. N. (2013). Credit portfolio management of Bangladesh Krishi Bank. Global Journal of Management and Business Research , 13 (12).

Bonti, G., Kalkbrener M., Lotz, C., Stahl, G., \& Bonti. G. (2005). Credit risk concentration under stress. From: http://citeseerx.ist.psu.edu/viewdoc/download? doi $=10.1 .1 .626 .2824 \&$ rep $=$ rep1\&type $=$ pdf

Comptrollers of the Currency Administrator of National. (1998). Loan portfolio management: Comptroller's hand book. From:https://www.occ.gov/publications/publications-bytype/comptrollers-handbook/loan-portfolio-management/pub-ch-loan-portfoliomgmt.pdf

Ivaskeviciute, I. M. (2008). The evaluation model of commercial bank loan portfolio. From:http://dx.doi.org/10.3846/1611-1699.2008.9.269-277.

Morris, J. (2001, December). Diversification in the credit portfolio:An overview of country practices. IMF Working Paper.

Nario, L., Pfister, T., Poppensieker, T., \& Stegemann, U. (2016, July). The evolving role of credit portfolio management. From http://www.mckinsey.com/business-functions/ risk/our-insights/the-evolving-role-of-credit-portfolio-management.

Tabak, M. Fazio M. \& Casueiro O. (2010). The effects of loan portfolio concentration on Brazilian Banks' Return \& Risk. The BancoCentral doBrasil Working Paper Series, 211.

Winton, A. (1999). Don't put all eggs in one basket? diversification and specilization in lending. From: https://ideas.repec.org/p/wop/pennin/00-16.html 